\title{
QUEEN'S
UNIVERSITY
BELFAST
}

\section{Natural mummies from Predynastic Egypt reveal the world's earliest figural tattoos}

Friedman, R., Antoine, D., Talamo, S., Reimer, P. J., Taylor, J. H., Wills, B., \& Mannino, M. A. (2018). Natural mummies from Predynastic Egypt reveal the world's earliest figural tattoos. Journal of Archaeological Science. https://doi.org/10.1016/j.jas.2018.02.002

Published in:

Journal of Archaeological Science

Document Version:

Peer reviewed version

Queen's University Belfast - Research Portal:

Link to publication record in Queen's University Belfast Research Portal

Publisher rights

(c) 2018 Elsevier Ltd. All rights reserved.

This manuscript version is made available under the CC-BY-NC-ND 4.0 license http://creativecommons.org/licenses/by-nc-nd/4.0/,which permits distribution and reproduction for noncommercial purposes, provided the author and source are cited.

\section{General rights}

Copyright for the publications made accessible via the Queen's University Belfast Research Portal is retained by the author(s) and / or other copyright owners and it is a condition of accessing these publications that users recognise and abide by the legal requirements associated with these rights.

Take down policy

The Research Portal is Queen's institutional repository that provides access to Queen's research output. Every effort has been made to ensure that content in the Research Portal does not infringe any person's rights, or applicable UK laws. If you discover content in the Research Portal that you believe breaches copyright or violates any law, please contact openaccess@qub.ac.uk. 


\title{
Natural mummies from Predynastic Egypt reveal the world's earliest figural tattoos
}

Renée Friedmana,b,1,2, Daniel Antoine ${ }^{b, 1,2}$, Sahra Talamoc ${ }^{a}$ Paula J. Reimer ${ }^{d}$, John H. Taylor $^{b}$, Barbara Wills ${ }^{b}$ and Marcello A. Mannino ${ }^{e, c}$

aFaculty of Oriental Studies, University of Oxford, Pusey Lane, Oxford OX1 2LG, UK 'The British Museum, Great Russell Street, London, WC1B 3DG, UK

'Department of Human Evolution, Max Planck Institute for Evolutionary Anthropology, Deutscher Platz 6, D-04103, Leipzig, Germany

d ${ }^{14}$ CHRONO Centre, Queen's University Belfast, Belfast, BT7 3EZ,UK

eDepartment of Archaeology and Heritage Studies, School of Culture and Society, Aarhus University, 8270 Højbjerg, Denmark

${ }^{1}$ These authors contributed equally to this work.

${ }^{2}$ Corresponding authors:

Renée Friedman friedman@hierakonpolis-online.org

Daniel Antoine dantoine@britishmuseum.org

The authors declare no conflict of interest.

Keywords: tattoos; natural mummies; radiocarbon dating; Egyptian Predynastic art; infrared imaging; isotopic analysis.

\begin{abstract}
The application of tattoos to the human body has enjoyed a long and diverse history in many ancient cultures. At present, the oldest surviving examples are the mainly geometric tattoos on the individual known as Ötzi, dating to the late 4th millennium BCE, whose skin was preserved by the ice of the Tyrolean Alps. In the Egyptian Nile valley, the arid climate has also promoted extensive soft tissue preservation. Here we report on the tattoos found during the examination of two of the best preserved naturally mummified bodies from Egypt's Predynastic (c. 4000-3100 BCE) period, making them the earliest extant examples from the Nile Valley. Figural tattoos that mirror motifs found in Predynastic art were observed on the right arm of one male and the right arm and shoulder of one female, demonstrating conclusively that tattooing was practiced in prehistoric Egypt. These findings overturn the circumstantial evidence of the artistic record that previously suggested only females were tattooed for fertility or even erotic reasons. Radiocarbon testing and datable iconographic parallels for the motifs indicate that these tattooed individuals are nearly contemporaneous with the Iceman, positioning them amongst the bearers of some of the oldest preserved tattoos in the world. At over five thousand years of age, they push back the evidence for tattooing in Africa by a millennium and provide new insights into the range of potential uses of tattoos in pre-literate societies by both sexes, revealing new contexts for exploring the visual language of prehistoric times.
\end{abstract}




\section{Introduction}

Interpretations of the artistic record and certain tool assemblages suggest the application of tattoos to the human body has enjoyed a long and diverse history in many cultures, perhaps going back to the Palaeolithic (Deter-Wolf, 2013; Deter-Wolf and Peres, 2013; Deter-Wolf et al., 2016). Absolute proof of this practice depends on the survival of human skin. The British Museum curates seven well-preserved examples of naturally mummified individuals from Egypt's Predynastic period (Dawson and Gray, 1968), the era preceding the country's unification by the first pharaoh at around 3100 BCE. All visible skin on these mummified individuals was examined for signs of body modification as part of a new program of conservation and research. Tattoos were discovered on two of the seven mummies: one male (EA 32751) and one female (EA 32752). Originally buried in shallow graves, their bodies were naturally desiccated by the heat, salinity and aridity of the Egyptian desert. The bodies show none of the signs of the deliberate and invasive embalming that define later Egyptian funerary traditions, although some form of external treatment cannot be excluded (Jones et al., 2014). In addition to extensive skin and muscle survival, CT scans have revealed the remarkable preservation of the internal organs (Antoine and Ambers, 2014; Taylor and Antoine, 2014). All seven individuals are reported to come from the site of Gebelein located in the southern part of Upper Egypt, but little else is known of their burial context, identity or status. Six of them (EA 32751-32756) were obtained for the museum in 1899 by Sir E.A. Wallis Budge, who claimed to have been present at their excavation (Budge, 1920). The seventh body (EA 57353) was purchased subsequently at auction from the collection of de Rustafjaell (Dawson and Gray, 1968; de Rustafjaell 1909). Although the veracity of Budge's account has been questioned, his description of the grave goods and burial setting, as well as the flexed position of the bodies and still surviving remnants of animal hide, matting and linen covering them, are all typical attributes of the Predynastic burial tradition. The radiocarbon results, supported by isotopic data, on hair and bone collagen sampled from six of the bodies for this study (see below) now confirm this attribution, with collective dates ranging from 3932 to 3030 cal BC (68.2\% probability).

\section{Materials and methods}

\subsection{Infrared imaging and the Gebelein mummies}

As part of an on-going programme of reanalysis and conservation, the skin of each Predynastic natural mummy was examined using infrared imaging under both flash and ambient light conditions with a hand-held Panasonic Lumix DMC ZS19 camera, converted to $720 \mathrm{~nm}$ infrared by Kolari Vision. Tattoos were detected on the observable areas of the bodies of two individuals: EA32751, a male known as Gebelein Man A and currently on display in The British Museum's Early Egypt Gallery (Room 64), and EA32752, a female known as Gebelein Woman.

Remnants of the animal hide, matting and linen used to cover the bodies of these individuals are present but most of these wrappings were removed prior to their arrival at the Museum, most probably during excavation. The accessible skin on each individual was systematically photographed with the infrared camera in a series of overlapping views. The tattoos appeared distinctly as dark forms against the lighter areas of the skin, requiring no image manipulation. Given the fragile nature of 
the remains, the examination of each mummy was restricted to the areas easily accessible and most could not be lifted to examine the side on which they are resting. Bar one, these individuals had been buried in a crouched position on their left sides and stored in that position, so that generally only the right side of the body and full back was visible, although in some cases obscured by remnants of the original covering of hide, textile or matting, or hindered by poor skin preservation. The areas available for examination are summarized in Table 1. Only Gebelein Woman (EA32752) was robust enough to be examined on all sides. The limited access coupled with variable skin preservation leaves open the possibility that more tattoos were originally present and that others may be found on these individuals in the future.

\section{PLEASE ADD TABLE ONE HERE}

The preserved skin of the tattooed mummies was meticulously cleaned by experienced conservators. The designs are not superficial and appear to have been applied into the dermis layer of the skin. The strong signature of the tattoos detected by the infrared camera indicates the pigment was predominantly carbon-based, presumably some sort of soot (see Poon, 2008). No testing of the pigments has yet been undertaken to determine its composition (see for example Pabst et al., 2009, 2010). The sex of the tattooed mummies was confirmed by CT scan. Threedimensional images of the pelvis were scored using the dimorphic traits recommended in Buikstra and Ubelaker (1994) and Bruzek (2002). The scan also revealed that the male tattooed mummy's skeleton (EA 32751) was in the process of completing its growth and, based on the developmental data published in Scheuer and Black (2000), he was approximately 18-21 years old when he died (Antoine and Ambers, 2014).

\subsection{Radiocarbon and isotope analyses}

Both of the tattooed mummies (EA 32751 and EA 32752) are very well-preserved with little or no access to the skeleton. A small amount of bone recovered from the exposed skull of EA 32752 did not yield datable extracts (see below), and no bone could be sampled from EA 32751. To avoid damaging the body tissues, hairs were carefully removed from the heads and used for the radiocarbon analysis. The samples were pretreated at the ${ }^{14} \mathrm{CHRONO}$ Centre to remove potential contamination with a three step solvent extraction in a soxhlet distillation apparatus using first chloroform and methanol (2:1), then ethanol, and lastly water (Bruhn et al., 2001). In addition to the hair, two samples each of two standards (IAEA-C3 and TIRI B) were pretreated using the same method to ensure that there was no possibility of either ancient or modern carbon contamination from the solvent treatment. The samples were dried in an oven at $60^{\circ} \mathrm{C}$ overnight, weighed into pre-combusted quartz tubes with an excess of copper oxide ( $\mathrm{CuO}$ ), sealed under vacuum and combusted to carbon dioxide $\left(\mathrm{CO}_{2}\right)$. The $\mathrm{CO}_{2}$ was converted to graphite on an iron catalyst using the zinc reduction method (Slota et al., 1987). The ${ }^{14} \mathrm{C} /{ }^{12} \mathrm{C}$ and ${ }^{13} \mathrm{C} /{ }^{12} \mathrm{C}$ ratios were measured by accelerator mass spectrometry (AMS). The sample ${ }^{14} \mathrm{C} /{ }^{12} \mathrm{C}$ ratio was background corrected and normalised to the HOXII standard (SRM 4990C; National Institute of Standards and Technology). The radiocarbon ages were corrected for isotope fractionation using the AMS measured ${ }^{13} \mathrm{C} /{ }^{12} \mathrm{C}$ ratio which 
accounts for both natural and machine fractionation. The radiocarbon age and one standard deviation were calculated using the Libby half-life of 5568 years, following the methods of Stuiver and Polach (1977). No contamination from the solvent extraction was detected in either the modern IAEA-C3 or the circa one half-life TIRI B standards.

The other Gebelein mummies curated at the British Museum are not as extensively preserved and skeletal material could be obtained for radiocarbon dating. Bone collagen samples were successfully extracted at the Max Planck Institute for Evolutionary Anthropology (MPI-EVA; Leipzig, Germany) from non-tattooed Gebelein mummies for the radiocarbon and the isotopic analysis, following the pretreatment protocol based on Talamo and Richards (2011). In order to monitor contamination introduced during the pre-treatment stage, collagen from a cave bear bone kindly provided by D. Döppes (Klaus-Tschira AMS facility, Germany) was extracted with each batch of samples as a background. Elemental and stable isotopic data (percentage carbon and nitrogen content, carbon to nitrogen ratio, $\delta^{13} \mathrm{C}$ and $\delta^{15} \mathrm{~N}$ ) of extracted collagen were measured in-house at the MPI-EVA, and approximately 5 to $6 \mathrm{mg}$ weighed into pre-cleaned tin cups at the MPI-EVA and sent to the KlausTschira-AMS facility (lab code: MAMS). Samples were combusted in an Elemental Analyser and $\mathrm{CO}_{2}$ converted catalytically to graphite and dated using the MICADASAMS (Kromer et al., 2013). The isotopic values were measured at MPI-EVA on a ThermoFinnigan Delta $V$ Advantage isotope ratio mass spectrometer (IRMS) coupled to a Flash 2000 EA. Stable carbon isotope ratios are expressed relative to VPDB (Vienna PeeDee Belemnite) and stable nitrogen isotope ratios were measured relative to AIR [atmospheric N2 with an analytical error of $0.2 \%(1 \sigma)$ for $\delta^{13} \mathrm{C}$ and $\left.\delta^{15} \mathrm{~N}\right]$. In addition, stable isotopes $\left(\delta^{13} \mathrm{C}\right.$ and $\left.\delta^{15} \mathrm{~N}\right)$ and carbon to nitrogen ratios were measured on the pretreated hair samples from the tattooed mummies at the ${ }^{14} \mathrm{CHRONO}$ Centre using a Thermo Delta $\mathrm{V}$ elemental analyser - isotope ratio mass spectrometer (EA-IRMS).

\section{Results}

\subsection{Dating}

Radiocarbon dating on hair from the two tattooed mummies, and on bone collagen from four other mummies from Gebelein (Table 2), produced an age range consistent with Egypt's Predynastic period (c. 4000-3100 BCE). The hair sample from the tattooed female produced a radiocarbon age of $4497 \pm 32{ }^{14} \mathrm{C}$ BP (UBA33754), calibrated using IntCal13 in the OxCal 4.2 program (Ramsey, 2009; Reimer et al., 2013) to $3351-3092$ cal BC (2 $\sigma, 95.4 \%$ probability) and to $3334-3104$ cal BC $(1 \sigma, 68.2 \%$ probability). The sample from the male tattooed mummy produced a radiocarbon age of $4461 \pm 36{ }^{14} \mathrm{C} \mathrm{BP}$ (UBA-33753), calibrated to $3341-3017$ cal BC $(2 \sigma)$ and to $3327-3030$ cal BC $(1 \sigma)$, The results from both of the tattooed individuals correspond to the generally accepted dates for the latter part of the Predynastic period (Naqada IID-IIIB, see Hendrickx, 2006; Patch, 2011; Tassie, 2014).

\section{PLEASE ADD TABLE TWO HERE}




\subsection{The tattoos}

The male mummy (EA32751), known as Gebelein Man A, has been on display almost continuously since his discovery over 100 years ago, yet the indistinct dark smudges on his upper right arm raised little interest and remained unexamined. Appearing as faint markings under natural lighting condition, the tattoos can now be distinguished under infrared imaging as depicting two horned animals facing toward the front of the body (Fig. 1). The two images, one somewhat lighter line weight than the other, overlap slightly, with one placed below and in front of the other, possibly suggesting they were applied at different times. No other tattoos were found on the parts of the body currently visible.

\section{PLEASE ADD FIGURE ONE HERE}

Fig. 1. Tattoos on the Predynastic male mummy from Gebelein. Top: Infrared image of the male mummy known as Gebelein Man A (EA 32751). Lower left: Detail of the tattoos observed on his right arm under infrared light. Lower right: The mummy and tattoos under normal lighting conditions. Images courtesy of the Trustees of The British Museum.

Infrared examination of the female mummy (EA 32752), known as Gebelein Woman, revealed several tattoos (Fig. 2). A series of four small ' $S$ ' shaped motifs can be seen running vertically over the superior aspect of her right shoulder, crossing the joint between the humerus and scapula. Below them, on the lateral aspect of the upper right arm, is a linear motif that bends nearly 90 degrees toward the anterior of the body and has short perpendicular strokes at its extremities. Under natural lighting conditions the tattoos appear as vague greenish markings on the skin. An irregular dark line also runs horizontally across the lower abdomen, close to the level of the navel, but its origins and extent are impossible to ascertain at this time due to the tightly contracted position of the legs. No other tattoos or markings were found elsewhere on her body including the left side, which was also examined.

\section{PLEASE ADD FIGURE TWO HERE}

Fig. 2. Tattoos on the Predynastic female mummy from Gebelein. Infrared images of the mummy (EA 32752), with details of the tattoos observed on her upper right arm (upper left) and shoulder (upper right). An irregular dark line also runs horizontally across the lower abdomen (bottom). Images courtesy of the Trustees of The British Museum.

\subsection{Isotope analyses and quality controls}


Our research aimed to obtain absolute dates for each individual and, as part of this work, isotope analyses were conducted to ensure quality control and provide dietary insights that might reveal other distinct attributes of the tattooed individuals. Initially, bulk bone collagen samples (represented by eight samples) were to be used, but only two individuals (i.e. EA 32752 and EA 57353; Table 3) yielded extracts that fully match the quality criteria proposed by van Klinken (1999). The extract from EA 32755 has percentage yield, elemental and isotopic values compatible with wellpreserved collagen, but its atomic carbon to nitrogen ratio is just above the accepted range. The collagen data from these individuals are valid for palaeodietary reconstructions but the bone sample from EA 32752 (the female tattooed mummy) had a rather low yield $(0.6 \%)$ and the extract was not sufficient for AMS radiocarbon dating $(2.3 \mathrm{mg})$, which was only undertaken on the bone collagen of EA 32753, EA 32755, EA 32756 and EA 57353. Three well-preserved samples (EA 32753, EA 32755 and $E A$ 57353) have $\delta^{13} \mathrm{C}$ values ranging from $-20.0 \%$ to $-18.3 \%$ (mean $\delta^{13} \mathrm{C}$ : $-19.1 \pm 0.9 \%$ ) and $\delta^{15} \mathrm{~N}$ values ranging from $13.3 \%$ to $14.9 \%$ (mean $\delta^{15} \mathrm{~N}$ : $14.0 \pm 0.8 \%$ ). Overall, the carbon isotope values fall within the variability for terrestrial environments dominated by $\mathrm{C}_{3}$ plants. The sample from EA 57353 has a high $\delta^{13} \mathrm{C}$ value $\left(=-18.3 \%\right.$ ) for a pure $\mathrm{C}_{3}$ environment and it is, thus, possible that some of this individual's diet originated in a small proportion either from $\mathrm{C}_{4}$ plants or from the protein of animals that fed on such plants.

\section{PLEASE ADD TABLE THREE HERE}

The carbon isotope value of EA 57353 also differs from the Gebelein skeletal remains analyzed by lacumin et al. (1996; see discussion below). As this mummy was acquired at auction a decade after the other six, this raises the possibility that its reported provenance may not be correct. The two tattooed individuals (EA 32751 and EA 32752) have almost identical isotopic compositions as the other Gebelein mummies in the British Museum collection (in particular to EA 32753 and EA 32755, although their extracts fall just outside the quality criteria proposed by van Klinken, 1999).

\section{Discussion}

\subsection{The tattoos}

The horned animals found on Gebelein Man A are frequent elements in early Egyptian iconography but identifying the species intended remains a challenge (Graff, 2009). Based on the shape of its elaborate horns, as well as the long tail, the lower tattoo represents a bovid, most probably wild cattle (Bos primigenius). The downward curving horns and the humped shoulder of the upper tattoo suggest it is a Barbary sheep (Ammotragus lervia). Both animals are well-known in Predynastic art but the closest stylistic parallels are found among incised potmarks, carved ivories and decorated palettes (Fig. 3; Patch, 2011; Petrie, 1896) of the late and terminal phases of the period (Naqada IID-IIIA, conventionally situated at C. 3400-3200 BCE; see below), as well as in more difficult to date rock art (Hendrickx et al., 2009; Judd, 2009). While the significance of the Barbary sheep remains vague and its popularity 
dwindled at the beginning of the Dynastic age, the wild bull continued to play an important role in ancient Egyptian imagery. From at least the end of the Predynastic era onwards, it was a symbol of male power and virility, particularly that of the king (Hendrickx, 2002). CT scans reveal Gebelein Man A was a young man when he died (Antoine and Ambers, 2014) and may have worn the tattoos as symbols of power or strength. A cut in the skin over his left shoulder blade, as well as damage to the underlying muscle, scapula and $4^{\text {th }}$ rib, suggest he died from a stab wound to the back (Antoine and Ambers, 2014). While perhaps simply a victim of interpersonal violence, the radiocarbon age range obtained from analysis of his hair (below) corresponds to the date ascribed to numerous depictions of conflict in the process surrounding the so-called unification and the establishment of the Dynastic Egyptian nation state at about 3100 BCE (Hendrickx, 2014; Bestock, 2018).

\section{PLEASE ADD FIGURE THREE HERE}

Fig. 3. Artistic depiction of a Barbary sheep comparable to the tattoo on Gebelein Man A. The Barbary sheep carved on a ceremonial palette of the terminal Predynastic period shows the characteristic out-turned horns and hump at the shoulder as seen in the tattoo of Gebelein Man A (AN 1896-1908 E.3924 (C) Ashmolean Museum, University of Oxford).

The motifs tattooed on Gebelein Woman are more difficult to interpret but parallels exist in the visual culture of the second half of the Predynastic period (Naqada IICIID; ca. 3500-3300 BC). The linear motif on her arm is most similar to objects held by figures participating in ceremonial activities on the painted ceramics of the period (Fig. 4). They may be crooked staves, symbols of power and status, or representations of throw-sticks, or batons and/or clappers used in ritual dance (Graff, 2009). This identification is complicated by the fact that such objects are never depicted alone, but always in use by a human figure. In the case of the tattoo, incised on the right arm, the woman herself may be considered to be the actor, using the implement with every movement of her arm. Such an interpretation is reinforced by the recent discovery of tattoos on the body of a woman who lived during the late New Kingdom (1186-1069 BC). On her right arm a tattoo, possibly representing the handle of a sistrum (ritual rattle), is suggested to have been so placed that she virtually shook the handle with every move (Austin and Gobeil, 2016).

The S-motif on Gebelein Woman's shoulder is also present as an element of Predynastic pottery decoration (Fig. 4) and always appears in multiples, as seen in the tattoo. Initially suggested to represent birds in flight, more recently this motif has been interpreted as an abstract element used to emphasize or connect different aspects of the composition (Graff, 2009). With this function in mind, the two tattoos found on Gebelein Woman could be viewed as a group possibly emphasizing ceremonial or ritual activities undertaken by, or on behalf of, the bearer. Their locations suggest high visibility and may have denoted status through magical empowerment or cult knowledge. The figural and hieroglyphic tattoos observed exclusively on women from New Kingdom Egypt (see Austin and Gobeil, 2016; Watson, 2016) suggest such markings were protective, amuletic or cult orientated. 


\section{PLEASE ADD FIGURE FOUR HERE}

Fig. 4. Predynastic motifs similar to those tattooed on the female mummy from Gebelein. A ritual scene painted on a Predynastic pottery jar depicts multiple Smotifs and a man holding a curved implement. Both motifs are comparable to the tattoos on Gebelein Woman. (EA 49570; Images courtesy of the Trustees of The British Museum).

The question of tattooing in early Egypt had long been debated based on the evidence of female clay figurines, their bodies ornamented with a variety of motifs, both geometric and figural (Keimer, 1948, Bianchi, 1988; Tassie, 2003). These clay figurines are not especially prevalent in the Neolithic and Predynastic record (Stevenson, 2017) and of the roughly 250 examples, only 16 have body decorations. Of those, less than half have an excavated context. Most were fashioned with abbreviated arms or are armless, and the motifs are generally found on the torso (front and/or back) and along the legs. Only three have incised geometric motifs on their back or legs, and given the evidence of the actual tattooed bodies, the limited extent of the ornamentations and the incised method with which they were applied speak in favour of them representing tattoos (Friedman, 2017). Yet, from their rarity one might conclude that either tattooing was not a widespread phenomenon within Predynastic society or, more likely, that such personal marks were not relevant within the context these figurines were used.

More problematic are the Predynastic figurines with elaborate painted decoration over their bodies and face (see Hendrickx et al., 2009; Petrie, 1920). At least four of these figures have wavy lines on or near the shoulder (Petrie, 1920; Scharff, 1931; Donadoni-Roveri, 1988). These are reminiscent of the S-motif of the Gebelein Women's tattoo (Fig. 5), but the extensive nature of the other designs and their locations suggests that all or some of these motifs may represent body paint, especially in light of the clear importance given to the grinding and use of pigments during this period (Baduel, 2008).

\section{PLEASE ADD FIGURE FIVE HERE}

Fig. 5. Clay figurine of a female with painted body ornamentation were previously the only evidence to suggest the practice of tattooing in Predynastic Egypt. The motifs near the shoulder may represent tattoos, but the elaborate nature of the other designs on the front (upper right) and back (lower right) of the torso may be ritually applied body paint (Turin Inv. Suppl. 1146; courtesy of Museo Egizio Turino).

Such figurines have generally been regarded within the realm of fertility magic. However, based on later evidence, Hendrickx et al. (2009) have suggested that they instead represent the practitioners of that magic: the musicians and dancers who performed at ritual hunting and butchery events which took place in conjunction with various other ceremonies. The authors propose that once embellished with images of the Nilotic environment on the front of their bodies, including animals and 
vegetation, and the desert hunt featuring almost exclusively Barbary sheep on the back (Fig. 5), such performers embodied and mediated the dualities of river and desert, celebration and sacrifice, and life and death. If the actual tattoos found on the Gebelein mummies can be considered to have gender specific meaning or refer to gender specific roles, the Barbary sheep on the back of these figurines may also refer to the duality of male and female.

\subsection{Dating}

The attribution of absolute dates to the phases of the Predynastic period and their correlation with radiocarbon results gathered from across the country remains problematic (Hendrickx, 2006; Dee et al., 2014). Nevertheless, the earlier part of the tattooed mummies' broad calibrated age ranges correlate well with the calendrical dates generally ascribed to the late and terminal Predynastic Naqada IID-IIIA phases (3400-3200 BCE) and the date modelled from the radiocarbon data for this period by Dee et al. (2013) of 3377-3238 BC (2 $\sigma)$ (see Table 2 and Fig. 6). These are the phases within which the closest stylistic parallels for the tattooed motifs can be found (e.g. Patch, 2011). Based on the radiocarbon dates, the Gebelein tattoos are, approximately contemporary with the Alpine mummy known as Ötzi (3370-3100 cal BC; Deter-Wolf et al., 2016), and can be considered amongst the earliest surviving tattoos in the world (Figure 6). However, in contrast to the motivation suggested for some of the 61 tattoos found on Ötzi, the Iceman (Krutak, 2013; Samadelli et al., 2015), recent CT scans (Antoine and Ambers, 2014) did not reveal any underlying pathological conditions near or below the Gebelein tattoos.

\section{PLEASE ADD FIGURE SIX HERE}

Fig. 6. Probability distributions for the radiocarbon ages of the tattooed Gebelein mummies, Ötzi the Iceman (both in black) and the latter phases of the Predynastic period (Naqada IID-IIIA boundary; in red) with 1 and $2 \sigma$ ranges given as lines below. Radiocarbon dates are calibrated in IntCal13 (Reimer et al., 2013), with the model and boundaries calculated using OxCal 4.2 (Ramsey, 2009).

\subsection{Isotope analyses, quality controls, diet and identity}

The state of isotopic and elemental preservation of archaeological hair is not routinely tested (Lamb, 2016), but modern hair has carbon to nitrogen ratios between 3.0 and 3.8 (van Klinken, 1999). The hair samples from the tattooed mummies (EA 32751 and EA 32752) have, thus, slightly higher carbon to nitrogen ratios than modern specimens (Table 3). The isotopic data from the hair are similar to those from the bone collagen, with a mean $\delta^{13} \mathrm{C}$ value of $-20.3 \pm 0.3 \%$ and a mean $\delta^{15} \mathrm{~N}$ value of $14.3 \pm 0.8 \%$. These values are enriched relative to those of bone collagen, which is the opposite of what would be expected. In fact, O'Connell et al. (2001) have shown that bone collagen is usually enriched relative to hair keratin by $1.41 \%$ in $\delta^{13} \mathrm{C}$ and $0.86 \%$ in $\delta^{15} \mathrm{~N}$ (although these offsets were less marked in archaeological specimens). However, apart from Gebelein Woman (EA 32752) for 
whom we have data from both hair and bone, the bone collagen data were obtained from individuals who may have had different diets and lived at different times. In the case of EA 32752, provided all analyses were conducted on well-preserved tissues, the difference between the isotopic compositions of bone collagen (long term diet) and hair keratin (recent diet) may indicate either: (a) a change in diet in favour of foods from less arid environments, and/or (b) a movement from more arid areas than those present at Gebelein, and/or (c) simply that the isotopic composition of the hair reflects the diet of a time of the year when consumption was centred on resources with lower $\delta^{13} \mathrm{C}$ and $\delta^{15} \mathrm{~N}$ compositions than the yearly average. Without comparative data, little more can be said, but these results present avenues for future research.

The carbon and nitrogen isotope analyses conducted on the bone collagen and hair show that the diets of the Gebelein individuals curated at The British Museum were based on resources from habitats dominated by $C_{3}$ plants. A similar result was obtained in a study of Gebelein mummies stored at the Egyptian Museum of Turin (lacumin et al., 1996), although in this case the mean $\delta^{13} \mathrm{C}$ value was $-19.4 \%$ and the mean $\delta^{15} \mathrm{~N}$ value $12.2 \%$. A recent study by Touzeau et al. (2014) has also shown that ancient Egyptians from the Nile Valley consumed almost exclusively $\mathrm{C}_{3}$ plantbased resources and that, although the contribution of meat is difficult to estimate in these environments (given the high $\delta^{15} \mathrm{~N}$ terrestrial plant baseline), animal foods may have contributed around $50 \%$ of dietary protein. A similar diet can be hypothesized for The British Museum Predynastic mummies, which, as mentioned above, had almost identical isotopic compositions that suggest (based on the limited data available) a level of dietary homogeneity compatible with belonging to the same cultural group and consuming locally-available foods.

Both the $\delta^{15} \mathrm{~N}$ values from the hair keratin from the tattooed mummies EA 32751 and EA 32752, and the bone collagen of EA 32752, have isotopic values higher than most individuals analyzed by Touzeau et al. (2014). In the absence of isotopic baselines from contemporary local fauna, it is hard to establish the origin and proportion of the animal protein consumed, but this may have included moderate quantities of terrestrial herbivore meat and/or aquatic fauna (Thompson et al., 2005). The broad dietary reconstruction for the Gebelein mummies proposed here is in line with zooarchaeological evidence for the Predynastic period, which suggests a wide range of wild and domestic animals were exploited. Fish constituted around $17 \%$ of identified fauna from Hierakonpolis, with lesser evidence that other aquatic animals and birds were also consumed here and at other sites (Guautier and van Neer, 2009; Gamza and Irish, 2012; for detailed tables see Linseele et al., 2009). In addition, the $\delta^{13} \mathrm{C}$ values align with published archaeobotanical data and suggest that the wide range of plant foods exploited were dominated by cereals with a $\mathrm{C}_{3}$ photosynthetic pathway, such as emmer wheat and barley, and that $\mathrm{C}_{4}$ plants such as millet were rarer (Fahmy, 2005; Gamza and Irish, 2012). However, the stable isotope data for the Gebelein mummies from The British Museum contrasts markedly with those of ancient Nubian people, who consumed considerably higher proportions of $\mathrm{C}_{4}$ plants or the animals that fed on them (Thompson et al., 2008).

Overall, the carbon and nitrogen isotope data obtained by analyzing the isotopes of the Gebelein mummies stored at the British Museum confirm that these individuals had diets typical of a largely agrarian society, such as that of late Predynastic Egypt (Hassan, 1988), and support the notion that they may all have belonged to the same 
group. With the exception of EA 57353's high $\delta^{13} \mathrm{C}$ value, the isotope data range is narrow, compatible with what would be expected for a group with a similar diet. The tattooed individuals cannot, therefore, be clearly set apart from the rest of the Gebelein mummies on isotopic grounds.

\section{Conclusion}

502

Datable iconographic parallels for the tattooed motifs and the radiocarbon ages from the bodies all point towards a late and terminal Predynastic date, and confirm that the mummies from Gebelein are the earliest known tattooed individuals in the Nile valley. Isotope analyses conducted on the bone collagen and hair also suggest that their diets were similar to that observed in other Predynastic mummies (lacumin et al., 1996), and largely based on resources from habitats dominated by plants with a $\mathrm{C}_{3}$ photosynthesic pathway. With radiocarbon dates ranging from 3351 to 3017 cal BC (95.4\% probability), the tattooed individuals are nearly contemporaneous with Ötzi, the Alpine mummy (3370-3100 cal BC; from Deter-Wolf et al., 2016), making them the bearers of some of the oldest surviving tattoos in the world. In contrast to Ötzi's mainly geometric tattoos, these tattoos mirror motifs found on contemporaneous figural art. Previously, only rare examples of female figurines ornamented with both geometric and figural motifs had suggested the practice of tattooing during the Neolithic and Predynastic periods in Egypt. The presence of painted or incised motifs exclusively on female figurines had led to the belief that tattooing was gender restricted and applied to women to enhance fertility. The observation of tattoos on Gebelein Man A now shows that visible body modification concerned both sexes.

We can only speculate on the method and context in which the tattoos were applied. A set of copper needles found in a Naqada III grave (Tassie, 2003) as well as the copper awls present within the burials predominately of women in contemporaneous A-Group Nubia (Nordström, 2002) have been interpreted as tattooing implements. Recent research has shown that polished bone awls are equally as effective for this purpose (Deter-Wolf and Peres, 2013), and the presence of such awls as part of a kit including pigments, resins, amulets and incense in the grave of an older woman at Hierakonpolis suggests that tattooing was in the hands of specialists and accompanied various rituals and ceremonies (Friedman, 2017). That at least two out of the seven well-preserved Predynastic mummies curated at The British Museum were tattooed may indicate that the practice was more widespread than the archaeological and artistic record allows us to see. Applied to both males and females and intended to be highly visible, the purpose of these figural tattoos may have differed between sexes, referencing perhaps status, bravery, cult/magical knowledge or protection. The exact function or meaning of these ancient indelible body marks, to both the Predynastic bearer and the viewer, remain to be fully elucidated by further discoveries. As the oldest known tattooed figural motifs, they add to our understanding of the range of potential uses of tattoos in pre-literate societies, provide new media and context for understanding visual language at the dawn of Ancient Egyptian civilization and expand our view of the practice of body modification in prehistoric times. 


\section{Acknowledgements}

We thank the Trustees of The British Museum and the Department of Ancient Egypt and Sudan, particularly Neal Spencer, for allowing us to sample the Gebelein mummies and Anna Davies-Barrett for proof reading the paper. The work was supported by the Institute for Bioarchaeology, British Museum, London. The pretreatments and analyses conducted at the Max Planck Institute in Leipzig were funded by the Max Planck Society. For this research work we are indebted to JeanJacques Hublin for support and to Annabell Reiner, Lysann Rädisch and Sven Steinbrenner of the Department of Human Evolution at the MPI-EVA for technical assistance. We thank the staff in the ${ }^{14} \mathrm{CHRONO}$ Centre for technical assistance. We also thank James Rossiter and Claire Thorne for help with the imagery and the Museo Egizio in Turin for permission to use the image of the female figurine.

\section{References}

Antoine, D., Ambers, J., 2014. The Scientific Analysis of Human Remains from the British Museum Collection: Research Potential and Examples from the Nile Valley, in: Fletcher, A., Antoine, D., Hill, J.D. (Eds.), Regarding the Dead: Human Remains in the British Museum. British Museum Press, London), pp. 20-30.

Austin, A., Gobeil, C., 2016. Embodying the Divine. A Tattooed Female Mummy from Deir el Medina. Bulletin du l'Institut Francais d'Archeologie Orientale 116, 23-46.

Baduel, N., 2008. Tegumentary Paint and Cosmetic Palettes in Predynastic Egypt: Impact of those Artefacts on the Birth of the Monarchy, in: Midant-Reynes, B., Tristant, Y. (Eds.), Egypt at its Origins 2. Proceedings of the International Conference "Origins of the State. Predynastic and Early Dynastic Egypt," Toulouse (France), 5th-8th September 2005. Orientalia Lovaniensia Analecta 172, Leuven, pp. 1057-1090.

Bestock, L., 2018. Violence and Power in Ancient Egypt: Image and Ideology before the New Kingdom. Routledge, London.

Bianchi, R.S.,1988. Tattoo in Ancient Egypt, in Rubin, A. (Ed.), Marks of Civilization: Artistic Transformation of the Human Body. University of California, Los Angeles, pp. $21-28$.

Bruhn, F., et al., 2001. Chemical Removal of Conservation Substances by 'Soxhlet'Type Extraction. Radiocarbon 43, 229-237.

Bruzek, J., 2002. A Method for Visual Determination of Sex, Using the Human Hip Bone. Am J. Phys. Anthropol. 117, 158-168.

Budge, E.A.W., 1920. By Nile and Tigris: a Narrative of Journeys in Egypt and Mesopotamia on Behalf of the British Museum Between the Years 1886 and 1913. John Murray, London. 
Buikstra, J.E., Ubelaker, D.H., 1994. Standards for data collection from human

skeletal remains. Arkansas Archaeological Survey Research Series No. 44, Arkansas.

Dawson Warren, R., Gray, P.H.K., 1968. Catalogue of Egyptian Antiquities in the British Museum. I. Mummies and Human Remains. British Museum, London.

Dee, M., et al., 2013. An Absolute Chronology for Early Egypt Using Radiocarbon Dating and Bayesian Statistical Modelling. Proc. R. Soc. A 469: 20130395; doi: 10.1098/rspa.2013.0395

Dee, M.W., et al., 2014. Radiocarbon dating and the Naqada relative chronology. J. Archaeol. Sci. 46: 319-323.

Deter-Wolf, A., 2013. The Material Culture and Middle Stone Age Origins of Ancient Tattooing, in: Della Casa, P., Witt, C. (Eds.), Tattoos and Body Modifications in Antiquity: Proceedings of the Sessions at the Annual Meetings of the European Association of Archaeologist in The Hague and Oslo, 2010/11. Chronos-Verlag, Zurich, pp. 15-26.

Deter-Wolf, A., Peres, T.M., 2013. Flint, Bone, and Thorns: Using Ethnohistorical Data, Experimental Archaeology, and Microscopy to Examine Ancient Tattooing in Eastern North America, in: Della Casa, P., Witt, C. (Eds.), Tattoos and Body Modifications in Antiquity: Proceedings of the Sessions at the Annual Meetings of the European Association of Archaeologist in The Hague and Oslo, 2010/11. ChronosVerlag, Zurich, pp. 35-48.

Deter-Wolf, A., et al., 2016. The World's Oldest Tattoos. J. Archaeol. Sci.: Reports 5, $19-24$.

Donadoni Roveri, A.M., 1988. La civilisation des égyptiens. Les croyances religieuses. Torino

Fahmy, A.G., 2005. Missing plant macro remains as indicators of plant exploitation in Predynastic Egypt. Veget. Hist. Archaeobot. 14, 287-294.

Friedman, R., 2017. New Tattoos from Ancient Egypt: Defining Marks of Culture, in: Krutak, L., Deter-Wolf, A. (Eds.), Ancient Ink: the Archaeology of Tattooing.. University of Washington Press, Seattle, pp. 11-37.

Gamza, T., Irish, J., 2012. A Comparison of Archaeological and Dental Evidence to Determine Diet at a Predynastic Egyptian Site. Int. J. Osteoarchaeol. 22, 398-408.

Gautier, A., van Neer, W., 2009. Animal remains from predynastic sites in the Nagada region, Middle Egypt. Archaeofauna 18, 27-50.

Graff, G., 2009. Les Peintures sur Vases de Naqada I-Naqada II: Nouvelle Approche Sémiologique de l'Iconographie Prédynastique. Leuven University Press, Leuven. 
Hassan, F.A., 1988. The Predynastic of Egypt. J. World Prehist. 2, 135-185.

Hendrickx, S., 2002. Bovines in Egyptian Predynastic and Early Dynastic Iconography, in: Hassan, F.A. (Ed.), Droughts, Food and Culture: Ecological Change and Food Security in Africa's Later Prehistory. Plenum, New York-London, pp. 275318.

Hendrickx, S., 2006. Predynastic-Early Dynastic chronology, in: Hornung, E., Krauss, R., WARBURTON, D.A. (Eds.), Ancient Egyptian chronology. Handbook of Oriental Studies. Section 1: Near and Middle East 83. Leiden, pp. 55-93, 487-488.

Hendrickx, S., 2014. The Emergence of the Egyptian State, in: Renfrew, C., Bahn, P. (Eds.), The Cambridge World Prehistory Vol. 1. Cambridge University Press, Cambridge, pp. 259-278.

Hendrickx, S., et al., 2009. Late Predynastic/Early Dynastic Rock Art Scenes of Barbary Sheep Hunting from Egypt's Western Desert. From capturing Wild Animals to the 'Women of the Acacia House', in: Riemer, H., Förster, F., Herb, M., Pöllath, N. (Eds.), Desert Animals in the Eastern Sahara: Status, Economic Significance and Cultural Reflection in Antiquity. Colloquium Africanum 4, Heinrich-Barth Institut, Cologne, pp. 189-244.

lacumin, P., et al., 1996. An Isotopic Palaeoenvironmental Study of Human Skeletal Remains from the Nile Valley. Palaeogeogr. Palaeoclimatol. Palaeoecol. 126, 15-30.

Jones, J., et al., 2014. Evidence for Prehistoric Origins of Egyptian Mummification in Late Neolithic Burials. PLoS ONE 9: e103608. https://doi.org/10.1371/journal.pone.0103608

Judd, T., 2009. Rock Art of the Eastern Desert of Egypt: Content, Comparisons, Dating and Significance. British Archaeological Reports Publishing, London.

Keimer, L., 1948. Remarques sur le Tatouage dans l'Égypte Ancienne [Notes on Tattooing in Ancient Egypt]. Memoires Presentés à l'Institut D'Égypte Vol. 53. L'institut Français d'Archéologie Orientale, Cairo.

Kelvin, W.C., 2008. In Situ Chemical Analysis of Tattooing Inks and Pigments: Modern Organic and Traditional Pigments in Ancient Mummified Remains. Unpublished Ph.D. dissertation, University of Western Australia

van Klinken, G.J., 1999. Bone Quality Indicators for Palaeodietary and Radiocarbon Measurements. J. Archaeol. Sci. 26, 687-695.

Kromer, B., et al., 2013. MAMS - A New AMS Facility at the Curt-Engelhorn-Centre for Achaeometry, Mannheim, Germany. Nucl. Instr. Meth. Phys. Res. B 294, 11-13.

Krutak, L., 2013. The Power to Cure: A Brief History of Therapeutic Tattooing, in: Della Casa, P. (Ed.), Tattoos and Body Modifications in Antiquity. Chronos Verlag, Zurich, pp. 27-34. 
Lamb, A.L., 2016. Stable Isotope Analysis of Soft Tissues from Mummified Human

Remains. Environ. Archaeol. 21, 271-284.

Linseele, V., et al., 2009. Special animals from a special place? The fauna from HK29A at Predynastic Hierakonpolis. J. Am. Res. Center in Egypt 45, 105-136.

Nordström, H.-A. 2002. The Nubian A-Group: Women and Copper Awls, in: Bács, T. (Ed.), A Tribute to Excellence. Studies offered in Honor of Enrö Gaál, Ulrich Luft, Lászlo Török. Studia Aegyptiaca XVII, Budapest, pp. 361-372.

O'Connell, T.C., et al., 2001. Isotopic Comparison of Hair, Nail and Bone: Modern Analyses. J. Archaeol. Sci. 28, 1247-1255.

Pabst, I., et al., 2009. The tattoos of the Tyrolean Iceman: a light microscopical, ultrastructural and element analytical study. J. Archaeol. Sci. 36, pp. 2335-2341.

Pabst, M.A., et al., 2010. Different staining substances were used in decorative and therapeutic tattoos in a 1000-year-old Peruvian mummy. J. Archaeol. Sci. 37, 32563262.Patch, D.C., 2011. Dawn of Egyptian Art. Metropolitan Museum of Art, New York.

Petrie, W.M.F., 1896. Naqada and Ballas. Bernard Quaritch, London.

Petrie, W.M.F., 1920. Prehistoric Egypt. Egyptian Research Account \& British School of Archaeology in Egypt 31, London.

Ramsey, C.B., 2009. Bayesian Analysis of Radiocarbon Dates. Radiocarbon 51, 337-360.

Reimer, P.J., et al., 2013. IntCal13 and Marine13 Radiocarbon Age Calibration Curves 0-50,000 Years cal BP. Radiocarbon 55, 1869-1887.

de Rustafjaell, R., 1909. The Light of Egypt : From Recently Discovered Predynastic and Early Christian Records. Kegan Paul, Tench and Trubner, London.

Samadelli, M., et al., 2015. Complete Mapping of the Tattoos of the 5300-year-old Tyrolean Iceman. J. Cult. Herit. 16, 753-758.

Scharff, A., 1931. Die Altertümer der Vor- und Frühzeit Ägyptens. I. Staatliche Museen zu Berlin. Mitteilungen aus der ägyptischen Sammlung 4, Berlin.

Scheuer, L., Black, S., 2000. Developmental Juvenile Osteology. Academic Press, London.

Slota, Jr P.J., et al., 1987. Preparation of Small Samples for ${ }^{14} \mathrm{C}$ Accelerator Targets by Catalytic Reduction of CO. Radiocarbon 29, 303-306.

Stevenson, A., 2017. Predynastic Egyptian Figurines. In The Oxford Handbook of Prehistoric Figurines, edited by Timothy Insoll. Oxford University Press, Oxford. 
745 Stuiver, M., Polach, H.A., 1977. Discussion: Reporting of ${ }^{14} \mathrm{C}$ Data. Radiocarbon 19, 746 355-363.

Talamo, S., Richards, M., 2011. A Comparison of Bone Pretreatment Methods for 749 AMS Dating of Samples >30, 000 BP. Radiocarbon 53, 443-449.

750 Tassie, G.J., 2003. Identifying the Practice of Tattooing in Ancient Egypt and Nubia. 751 Papers from the Institute of Archaeology 14, 85--101.

752 Tassie, G.J., 2014. Prehistoric Egypt. Golden House, London.

753 Taylor, J.H., Antoine, D., 2014. Ancient Lives, New Discoveries: Eight Mummies, 754 Eight Stories. British Museum Press, London.

Thompson, A.H., et al., 2005. Isotopic Palaeodiet Studies of Ancient Egyptian Fauna and Humans. J. Archaeol. Sci. 32, 451-463.

Thompson, A.H., et al., 2008 Stable Isotopes and Diet at Ancient Kerma, Upper Nubia (Sudan). J. Archaeol. Sci. 35, 376-387.

Touzeau, A., et al., 2014. Diet of Ancient Egyptians Inferred from Stable Isotope Systematics. J. Archaeol. Sci. 46. 114-124.

Watson, T., 2016. Intricate Animal and Flower Tattoos Found on Egyptian Mummy. Nature 533, 155. 